University of Nebraska - Lincoln

DigitalCommons@University of Nebraska - Lincoln

1970

\title{
Influence of Dietary Supplements of Cholesterol and Vitamin D on Certain Components of the Blood and Body of Growing-Finishing Swine
}

\author{
M. H. Jurgens \\ lowa State University \\ E. R. Peo, Jr. \\ University of Nebraska-Lincoln
}

Follow this and additional works at: https://digitalcommons.unl.edu/animalscifacpub

Part of the Animal Sciences Commons

Jurgens, M. H. and Peo, Jr., E. R., "Influence of Dietary Supplements of Cholesterol and Vitamin D on Certain Components of the Blood and Body of Growing-Finishing Swine" (1970). Faculty Papers and Publications in Animal Science. 633.

https://digitalcommons.unl.edu/animalscifacpub/633

This Article is brought to you for free and open access by the Animal Science Department at DigitalCommons@University of Nebraska - Lincoln. It has been accepted for inclusion in Faculty Papers and Publications in Animal Science by an authorized administrator of DigitalCommons@University of Nebraska - Lincoln. 


\title{
INFLUENCE OF DIETARY SUPPLEMENTS OF CHOLESTEROL AND VITAMIN D ON CERTAIN COMPONENTS OF THE BLOOD AND BODY OF GROWING-FINISHING SWINE ${ }^{1}$
}

\author{
M. H. Jurgens ${ }^{2}$ and E. R. Peo, JR. ${ }^{3}$ \\ Nebraska Agricultural Experiment Station, Lincoln
}

\begin{abstract}
$\mathrm{T}$ HE American public has been made extremely conscious of the concept that saturated fat and cholesterol may be involved in atherosclerosis in man. Likewise, because of their content of cholesterol and saturated fatty acids, animal products have become engrossed in a controversy concerning their role in the atherogenic process. No definite conclusions have been made in this area and until further research advances in the field of atherosclerosis, the animal scientist may have to concern himself with modifying the animal product in such a way that it will be more acceptable to the American public. The degree to which this may be accomplished will vary with the species of animal. Swine are somewhat more unique in this respect because moderate changes in the diet can result in dramatic changes in the composition and type of fat deposited in the swine carcass.

A review of the literature indicates few studies concerning the relationship between vitamin $D$ and cholesterol-compounds functional in the body and which have a similar chemical structure. No information could be found in the literature concerning the relationship between excess dietary vitamin $\mathbf{D}$ and body cholesterol levels of swine. Thus, the present investigations were undertaken to study the effects of dietary supplements of vitamin $\mathrm{D}$ and cholesterol upon the serum cholesterol level of the blood and upon body growth and fat composition of growing-finishing swine.
\end{abstract}

\section{Experimental Procedure}

The pigs used in all experiments were fed a $16 \%$ protein corn-soybean meal diet containing $440 \mathrm{IU}$ of vitamin $\mathrm{D}_{2}$ prior to allotment to the experiments described below. Physical

1 Published with the approval of the Director as Paper No. 2646, Journal series, Nebr. Agr. Exp. Sta.

2 Present address: Iowa State University, Ames.

3 Department of Animal Science. Acknowledgement is made to John Welch for assistance in development of certain of the laboratory procedures and to P. J. Cunningham and associates for care of the experimental animals. plant limitations did not permit the conduct. of these studies in the absence of sunlight.

Experiment 1. Forty-eight crossbred barrows and gilts (16 females; 32 males) averaging $30 \mathrm{~kg}$ were assigned at random within sex to two replications of a $2 \times 2$ factorial arrangement of four treatments ( 6 pigs per pen: 12 pigs per treatment). The pigs were housed and fed in concrete-floored, open-shed type experimental units which were equipped with self-feeders and waterers. The experiment was conducted over a period of 70 days and terminated when the pigs reached an average body weight of 95 kilograms.

Composition of the experimental diets is presented in table 1 . The $14 \%$ protein cornsoybean meal basal diet (diet A) was calculated to be completely void of cholesterol and vitamin $\mathrm{D}_{2}$. Diet $\mathrm{B}$ was formulated to contain $1,100 \mathrm{IU} / \mathrm{kg}$ of supplemental vitamin $\mathrm{D}_{2}$. Crystalline cholesterol was included at 440 $\mathrm{mg} / \mathrm{kg}$ in $\operatorname{diet} \mathrm{C}$, and diet $\mathrm{D}$ was supplemented with both vitamin $\mathrm{D}_{2}(1,100 \mathrm{IU} / \mathrm{kg})$ and cholesterol $(440 \mathrm{mg} / \mathrm{kg})$.

Criteria of response were backfat thickness, and cholesterol content of blood serum, longissimus dorsi muscle and backfat.

Experiment 2. Seventy-two crossbred barrows and gilts averaging $35 \mathrm{~kg}$ were assigned at random to two replications of six experi. mental treatments. Six pigs were allotted to each pen, 12 pigs per treatment with equal distribution for sex. Housing and management were as described for the first experiment. The first four experimental treatments (diets A to $\mathrm{D}$ ) were also the same (see table 1 ). Two additional treatments were included, diet $\mathbf{E}$ containing supplements of $440 \mathrm{mg} / \mathrm{kg}$ crystalline cholesterol with $2,200 \mathrm{IU} / \mathrm{kg}$ of vitamin $\mathrm{D}_{2}$ and $\operatorname{diet} \mathrm{F}$ formulated to contain 1,320 $\mathrm{mg} / \mathrm{kg}$ of supplemental cholesterol (three times the level found in $\operatorname{diet} \mathrm{C}$ ) and no supplemental vitamin $\mathbf{D}_{2}$. The experiment was terminated after 68 days when the pigs reached an average body weight of 95 kilograms.

Criteria of response were backfat thickness, 
TABLE 1. COMPOSITION OF EXPERIMENTAL DIETS ${ }^{\text {a }}$

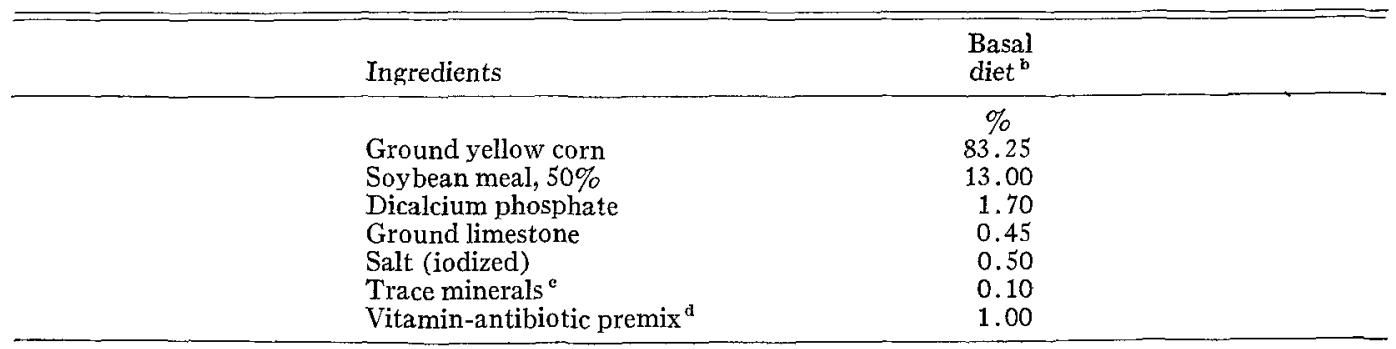

Basal $14 \%$ protein corn-soybean meal diet is common over all treatments.

- Calculated analyses.

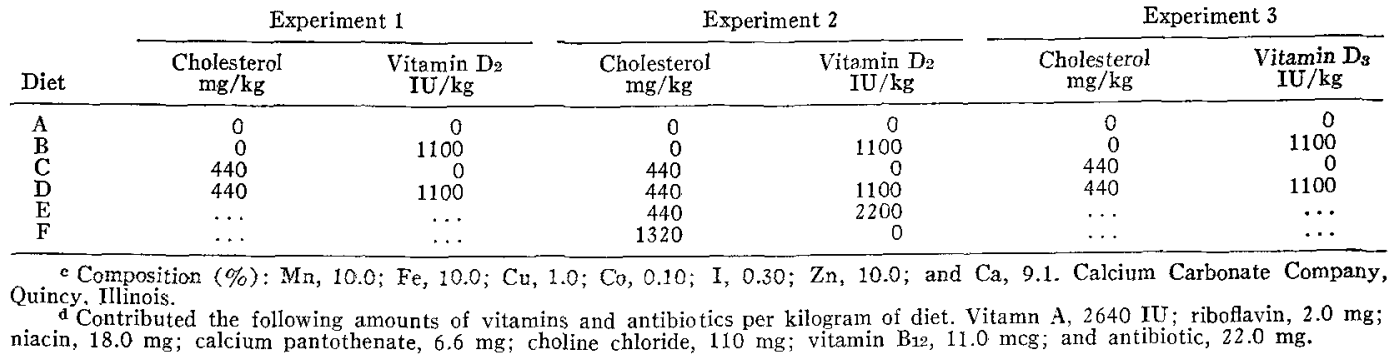

area and percentage of fat in the $l$. dorsi, blood serum cholesterol, and cholesterol and fatty acid content of the $l$. dorsi and inner and outer layers of backfat.

Experiment 3. Twenty-four crossbred barrows and gilts averaging $65 \mathrm{~kg}$ were assigned at random to four experimental treatments. Six pigs were allotted to each treatment with equal distribution for sex. Housing and management were as described for the first experiment. The four experimental treatments (diets A to D) were also the same (see table 1) except that vitamin $\mathrm{D}_{3}$ was substituted for vitamin $\mathrm{D}_{2}$. The experiment was terminated after 56 days when the pigs reached an average body weight of 114 kilograms.

Criteria of response were the same as indicated for the second experiment. In addition, cholesterol and fatty acid contents of the liver were determined.

In all three experiments, approximately 10 $\mathrm{ml}$ of blood were collected from each pig and total serum cholesterol was measured initially and at the termination of each experiment. B \& D vacutainer tubes ${ }^{4}$ with $3.8 \mathrm{~cm}, 20$ gauge needles were used to obtain blood from the brachial veins. The collected blood was allowed to coagulate and was then centrifuged and the serum removed from chemical analysis.

The carcasses were allowed to cool for $24 \mathrm{hr}$. after slaughter and the backfat thickness was

\footnotetext{
${ }^{4}$ Becton-Dickinson, Rutherford, New Jersey.
}

determined from the average of three measurements taken at the first rib, last rib and last lumbar vertebra.

The loins from carcasses in the first experiment were not divided for sampling but core samples for chemical analysis of the $l$. dorsi and backfat were taken from the chilled carcass by means of a $7 \mathrm{~mm}$ diameter stainless steel core sampling probe.

The right loin from each carcass in the second and third experiments was divided between the 10th and 11th rib. Area of the $l$. dorsi was determined by standard procedures.

Since sample size was not considered large enough in the first experiment, the 11-12 th rib section of the loin from pigs in the second and third experiments was removed and the l. dorsi in the sample was trimmed of excess fat and frozen. The frozen muscle samples were ground with a power grinder using a plate with $3.2 \mathrm{~mm}$ holes. After grinding, the samples were re-frozen and stored until needed for cholesterol and fatty acid analyses. A sample of backfat (inner and outer layer) was also taken from over the 11-12th rib section and stored frozen.

In the third experiment, a cross-sectional sample of liver was obtained from the diaphramatic lobe to determine cholesterol and fatty acid contents.

Fat content of the $l$. dorsi in the second experiment was determined on duplicate samples by a modified Babcock method (Jur- 
gens et al., 1967). The fat content of the $l$. dorsi from carcasses in the third experiment was determined by standard fat extraction methods as described by A.O.A.C. (1960).

Total blood serum cholesterol was determined on duplicate samples by a colormetric method described by Pearson, Stern and McGavack (1953).

Cholesterol content of $l$. dorsi, backfat and liver was determined by modifying the method outlined by Stromer, Gall and Roberts (1966) to the extent that a $2 \mathrm{~g}$ wet tissue sample was extracted rather than a $4 \mathrm{~g}$ lyophilized sample.

A modification of the technique described by Morrison and Smith (1964) was employed to determine fatty acid content of the $l$. dorsi and inner and outer layers of backfat of pigs from the second and third experiments and of the livers from pigs on the third experiment.

Methyl esters of fatty acids of all the tissue samples were prepared using a solution ${ }^{5}$ consisting of a mixture of $20 \%$ boron fluoridemethanol (140 g BF per liter of methanol), $25 \%$ benzene and $55 \%$ of methanol. A JarrellAsh, Model 700 gas chromatograph, equipped with an argon ionization detector, was used for determining fatty acids. The following settings were employed: argon gas flow rate, $180 \mathrm{ml} / \mathrm{min}$; injector port temperature, 250 $\mathrm{C}$; detector temperature, $210 \mathrm{C}$; column temperature, $188 \mathrm{C}$; detector voltage, $1,200 \mathrm{~V}$; and sensitivity, $1 \times 10^{-8}$ amperes full range. The column, $366 \mathrm{~cm} \times 6.35 \mathrm{~mm}$ O.D. stainless steel tubing, was packed with $16 \%$ diethylene glycol succinate on 90/100 mesh Anakrom $\mathrm{AB}$. Injected sample size varied from two to five mcl. The individual peaks were identified

5 Applied Science Laboratories, Inc., State College, Pennsyl- by comparing retention times of unknowns with those of a standard reference mixture of known composition and concentrations. Determinations were made for percentages of the following identified methyl esters of fatty acids: myristic $(14: 0)$, palmitic $(16: 0)$, palmitoleic (16:1), stearic $(18: 0)$, oleic $(18: 1)$ and linoleic (18:2).

Analyses of variances as outlined by Steel and Torrie (1960) were calculated on the data in each of the reported experiments.

\section{Results and Discussion}

Experiment 1. A summary of average backfat thickness and total cholesterol content of blood serum, $l$. dorsi, and backfat is presented in table 2. Backfat thickness was not significantly affected by dietary treatment but carcasses from gilts had less $(\mathrm{P}<.05)$ backfat than those from barrows $(3.7 v s .4 .2 \mathrm{~cm})$. The relationship between sex and backfat thickness of the animal is well documented (Bruner et al., 1958; Cox, 1963; Wagner et al., 1963) and the observation here was expected.

The addition of crystalline cholesterol to the basal diet resulted in elevated final blood cholesterol levels. Similar results have been reported with rats by Cuthbertson et al. (1959) and Pack and Loud (1965). Barrows and higher final blood cholesterol levels than the gilts $(102 v s .95 \mathrm{mg} / 100 \mathrm{ml})$. The difference approached significance and disagrees with those of Hill, Peifer and Lundburg (1958) and Cuthbertson et al. (1959), in studies with swine and rats, respectively, who reported females having higher blood cholesterol levels than intact males.

The supplementation of dietary cholesterol also increased the cholesterol content of the

TABLE 2. EFFECT OF LEVELS OF CHOLESTEROL AND VITAMIN D $D_{2}$ ON AVERAGE BACKFAT THICKNESS AND TOTAL CHOLESTEROL CONTENT OF BLOOD SERUM, LONGISSIMUS DORSI MUSCLE AND BACKFAT (EXPERIMENT 1)

\begin{tabular}{|c|c|c|c|c|c|c|}
\hline \multirow[b]{3}{*}{ Item } & \multirow{2}{*}{\multicolumn{2}{|c|}{ Sex }} & \multicolumn{4}{|c|}{$\begin{array}{c}\text { Treatment } \\
\text { (Cholesterol/Vitamin } \mathrm{D}_{2} \text { ) }\end{array}$} \\
\hline & & & \multirow{2}{*}{$\begin{array}{c}\mathrm{A} \\
0 / 0\end{array}$} & \multirow{2}{*}{$\begin{array}{c}\mathrm{B} \\
0 / \mathbf{1 1 0 0}\end{array}$} & \multirow{2}{*}{$\begin{array}{c}C \\
440 / 0\end{array}$} & \multirow{2}{*}{$\frac{D}{440 / 1100}$} \\
\hline & Barrows & Gilts & & & & \\
\hline No. pigs ${ }^{a}$ & 16 & 32 & 12 & 12 & $11^{\mathrm{b}}$ & 12 \\
\hline Avg backfat, $\mathrm{cm}^{\mathrm{c}}$ & 4.2 & 3.7 & 4.1 & 4.1 & 3.8 & 3.8 \\
\hline Initial blood chol., $\mathrm{mg} / 100 \mathrm{ml}$ & 98.4 & 82.8 & 88.3 & 84.8 & 97.2 & 81.6 \\
\hline Final blood chol., mg/100 ml & 102.0 & 95.0 & 96.1 & 94.4 & 102.8 & 95.3 \\
\hline L. dorsi chol., $\mathrm{mg} / \mathrm{g}$ wet tissue & 0.30 & 0.28 & 0.29 & 0.27 & 0.30 & 0.28 \\
\hline Backfat chol, mg/g wet tissue & 0.65 & 0.57 & 0.61 & 0.58 & 0.63 & 0.57 \\
\hline
\end{tabular}

4. Two replications, 6 pigs/pen.

b One pig was removed from treatment $\mathrm{C}$ because of failure to eat. c Sex effect sig. $\mathrm{P}<.05$. 
l. dorsi and backfat. However, the changes were small and not of statistical significance.

The inclusion of dietary vitamin $\mathrm{D}_{2}$ in the presence or absence of dietary cholesterol did not significantly reduce final cholesterol levels in blood, $l$. dorsi, and backfat. The trend toward a decrease in blood cholesterol is contrary to studies with rabbits reported by Ross and Campbell (1961), Myasnikov (1958) and DeLangen and Donth (1956) in which blood cholesterol was increased. It should be pointed out that there may be differences among species as well as the fact that the pigs on the experiment reported herein were growing animals; whereas, mature animals were used in other research.

The pattern of $l$. dorsi and backfat cholesterol content paralleled that of the blood levels with small changes due to dietary treatment.

Experiment 2. The effects of levels of cholesterol and vitamin $\mathrm{D}_{2}$ on blood and certain carcass traits of pigs from Experiment 2 is shown in table 3 . Average backfat thickness was not significantly affected by dietary treatment; however, as expected barrows had significantly $(\mathrm{P}<.01)$ greater backfat thickness than gilts ( 4.8 vs. $4.3 \mathrm{~cm}$ ).

The area of the $l$. dorsi and percentage of fat therein were significantly $(P<.01)$ larger and smaller, respectively, in gilts compared to barrows (29.7 vs. $26.9 \mathrm{~cm}^{2}$ and $4.4 v s$. $5.5 \%$ ). The larger $l$. dorsi area in gilts is in agreement with the work reported by Self, Bray and Reierson, (1957), Bruner et al. (1958), Judge (1964) and Brooks (1967). Wagner et al. (1963) and Brooks (1967) also reported a lower percentage of $l$. dorsi intramuscular fat in gilts compared to barrows.

The addition of vitamin $\mathrm{D}_{2}$ to the basal diet reduced $l$. dorsi area in both barrows and gilts. When the linear increases in dietary vitamin $\mathrm{D}_{2}$ were compared (diets $\left.\mathrm{C}, \mathrm{D}, \mathrm{E}\right)$, the percentage of $l$. dorsi fat increased $(\mathrm{P}<$ $.01)$ and decreased $(\mathrm{P}<.01)$ in barrows and gilts, respectively. This observation indicates a possible interaction between sex and level of dietary vitamin $\mathrm{D}_{2}$.

Feeding diets containing added cholesterol without vitamin $D_{2}$ resulted in a nonsignificant elevation in blood cholesterol levels compared to pigs on the basal diet. The highest blood level was observed in pigs fed the highest dietary cholesterol level. The increased levels were small, but nevertheless, were similar to the results obtained in the previous experiment (experiment 1). Studies with swine by Reiser et al. (1959) further support the positive relationship between dietary and blood cholesterol levels. In the present experiment, barrows tended to have higher blood cholesterol levels than gilts (107 vs. $103 \mathrm{mg} / 100 \mathrm{ml}$ ) which also agrees with the findings of the previous experiment.

The data suggest an interaction between dietary levels of vitamin $\mathrm{D}_{2}$ and cholesterol as related to final blood serum cholesterol levels. The addition of $1,100 \mathrm{IU} / \mathrm{kg}$ of vita$\min \mathbf{D}_{2}$ to the basal diet had no effect on final blood cholesterol levels, but when this amount of vitamin $D_{2}$ was fed in combination with $440 \mathrm{mg} / \mathrm{kg}$ cholesterol, blood cholesterol levels were lowered. The latter observation also agrees with results of the previous experiment. When twice the amount of vitamin $\mathrm{D}_{2}$ was added in combination with $440 \mathrm{mg} / \mathrm{kg}$ of cholesterol, the final blood levels were elevated above the level observed with the basal diet.

It appears evident from the data that dietary treatment may influence the blood cholesterol levels to some extent; however, tissue concentration seems to be quite stable. Only small changes in cholesterol level were observed in either the $l$. dorsi or inner and outer layers of backfat due to dietary treatment. Both layers of backfat contained similar concentrations of cholesterol and paralleled one another with changes in dietary treatment.

The fatty acid content of $l$. dorsi intramuscular fat and inner and outer layers of backfat is also summarized in table 3 . Only three principal saturated and three unsaturated fatty acids were chromatographically identified with the sum of myristic, palmitic and stearic representing the total for the saturates and palmitoleic, oleic and linoleic the unsaturates. A survey of the literature indicated these fatty acids were the major straight-chained, even-numbered, monocarboxylic acids present in mammalian lipids (Hanahan, 1960).

Variation in fatty acid levels of the three tissues did not follow any consistent pattern due to either dietary treatment or sex. The principal saturated fatty acid found was palmitic and the primary unsaturate was oleic acid. This is consistent with the findings of Sink et al. (1964), Greer et al. (1965) and Koch et al. (1968). Dietary treatment had no significant effect on total saturated fatty acid content of either intramuscular fat or backfat. However, the intramuscular fat from 
TABLE 3. EFFECT OF LEVELS OF CHOLESTEROL AND VITAMIN D2 ON BLOOD AND CERTAIN CARCASS TRAITS (EXPERIMEN'T 2)

\begin{tabular}{|c|c|c|c|c|c|c|c|c|}
\hline \multirow[b]{3}{*}{ Item } & \multirow{2}{*}{\multicolumn{2}{|c|}{ Sex }} & \multicolumn{6}{|c|}{$\begin{array}{l}\text { Treatments } \\
\text { (Cholesterol/Vitamin } \mathrm{D}_{2} \text { ) }\end{array}$} \\
\hline & & & \multirow{2}{*}{$\begin{array}{c}\mathrm{A} \\
0 / 0\end{array}$} & \multirow{2}{*}{$\underset{0 / 1100}{B}$} & \multirow{2}{*}{$\frac{\mathrm{C}}{440 / 0}$} & \multirow{2}{*}{$\underset{440 / 1100}{\text { D }}$} & \multirow{2}{*}{$\begin{array}{c}\mathrm{E} \\
440 / 2200\end{array}$} & \multirow{2}{*}{$\underset{1320 / 0}{\mathbf{F}}$} \\
\hline & Barrows & Gilts & & & & & & \\
\hline No. pigs ${ }^{2}$ & 36 & 36 & 12 & 12 & 12 & 12 & 12 & 12 \\
\hline Avg backfat, $\mathrm{cm}^{\mathbf{b}}$ & 4.8 & 4.3 & 4.6 & 4.6 & 4.6 & 4.4 & 4.5 & 4.5 \\
\hline L. dorsi area, $\mathrm{cm}^{2 \mathbf{b}}$ & 26.9 & 29.7 & 29.2 & 27.4 & 28.1 & 29.3 & 27.7 & 27.9 \\
\hline L. dorsi fat, $\%$ & 5.5 & 4.4 & 4.9 & 4.9 & 5.1 & 4.8 & 5.3 & 4.6 \\
\hline $\begin{array}{l}\text { Initial blood chol., } \\
\mathrm{mg} / 100 \mathrm{ml}\end{array}$ & 107.0 & 103.0 & 99.0 & 106.0 & 104.0 & 102.0 & 109.0 & 111.0 \\
\hline $\begin{array}{l}\text { Final blood chol., } \\
\mathrm{mg} / 100 \mathrm{ml}\end{array}$ & 107.0 & 103.0 & 101.0 & 105.0 & 102.0 & 99.0 & 110.0 & 111.0 \\
\hline $\begin{array}{l}\text { L. dorsi chol., } \mathrm{mg} / \mathrm{g} \\
\text { wet tissue } \\
\text { Inner backfat chol., }\end{array}$ & 0.40 & 0.38 & 0.36 & 0.39 & 0.41 & 0.40 & 0.40 & 0.40 \\
\hline $\begin{array}{l}\mathrm{mg} / \mathrm{g} \text { wet tissue } \\
\text { Outer backfat chol., }\end{array}$ & 0.62 & 0.62 & 0.62 & 0.64 & 0.61 & 0.60 & 0.63 & 0.64 \\
\hline $\mathrm{mg} / \mathrm{g}$ wet tissue & 0.63 & 0.61 & 0.61 & 0.64 & 0.64 & 0.60 & 0.61 & 0.62 \\
\hline \multicolumn{9}{|c|}{$\begin{array}{l}\text { Fatty acid composition } \\
\text { Intramuscular fat of } \\
\text { l. dorsi }\end{array}$} \\
\hline $14: 0$ & 2.5 & 2.7 & 2.8 & 2.6 & 2.5 & 2.6 & 2.6 & 2.4 \\
\hline $16: 0$ & $27: 2$ & 27.0 & 27.3 & 27.0 & 27.3 & 26.8 & 27.0 & 27.4 \\
\hline $18: 0^{\mathrm{b}, \mathrm{e}, \mathrm{f}}$ & 10.6 & 11.2 & 10.7 & 10.1 & 10.7 & 11.4 & 11.5 & 11.0 \\
\hline Total for sat'd. & 40.3 & 40.9 & 40.8 & 39.7 & 40.5 & 40.8 & 41.1 & 40.8 \\
\hline $16: 1$ & 5.7 & 5.7 & 5.9 & 5.8 & 5.6 & 5.7 & 5.6 & 5.5 \\
\hline $18: 1^{\mathbf{f}, \mathrm{g}}$ & 45.0 & 44.2 & 44.3 & 45.6 & 44.7 & 44.0 & 44.8 & 44.1 \\
\hline $18: 2$ & 9.1 & 9.1 & 8.9 & 8.8 & 9.1 & 9.4 & 8.6 & 9.6 \\
\hline \multicolumn{9}{|l|}{ Inner backfat } \\
\hline $14: 0^{\mathrm{h}}$ & 2.3 & 2.7 & 2.7 & 2.2 & 2.2 & 3.2 & 2.4 & 2.3 \\
\hline $16: 0$ & 26.0 & 26.1 & 25.1 & 25.3 & 27.2 & 26.3 & 26.8 & 25.8 \\
\hline $18: 0^{1}$ & 14.5 & 14.0 & 13.9 & 12.6 & 14.5 & 13.7 & 14.2 & 16.8 \\
\hline Total for sat'd. & 42.8 & 42.8 & 41.7 & 40.1 & 43.9 & 43.2 & 43.4 & 44.9 \\
\hline $16: 1^{\mathrm{b}}$ & 4.8 & 3.8 & 4.2 & 4.7 & 4.3 & 4.7 & 3.4 & 4.4 \\
\hline $18: 1^{j}$ & 43.4 & 44.0 & 44.4 & 45.2 & 43.8 & 42.8 & 43.0 & 43.0 \\
\hline $18: 2^{e}$ & 9.0 & 9.5 & 9.9 & 10.2 & 8.0 & 9.3 & 10.2 & 7.8 \\
\hline \multicolumn{9}{|l|}{ Outer backfat } \\
\hline $14: 0$ & 2.5 & 2.4 & 2.2 & 2.4 & 3.2 & 2.2 & 2.1 & 2.7 \\
\hline $16: 0^{\mathrm{g}}$ & 24.5 & 25.1 & 22.9 & 25.8 & 24.9 & 25.5 & 24.2 & 25.3 \\
\hline $18: 0$ & 11.5 & 11.2 & 11.2 & 11.8 & 10.4 & 11.2 & 10.6 & 12.8 \\
\hline Total for sat'd. & 38.5 & 38.6 & 36.3 & 40.0 & 38.5 & 38.9 & 36.9 & 40.8 \\
\hline $16: 1^{\mathrm{k}}$ & 4.2 & 4.4 & 4.7 & 4.2 & 4.6 & 3.9 & 4.4 & 4.1 \\
\hline $18: 1^{1}$ & 46.7 & 46.3 & 47.2 & 46.1 & 45.9 & 46.8 & 47.7 & 45.3 \\
\hline $18: 2$ & 10.6 & 10.6 & 11.8 & 9.7 & 11.0 & 10.4 & 11.0 & 9.8 \\
\hline
\end{tabular}

a Two replications; 6 pigs/pen.

c Linear effect of level of vitamin $\mathrm{D}$, $\mathrm{x}$ sex interaction $\mathrm{i} \cdots, \mathrm{P}<. \mathrm{Cl}$.

a Linear effect of level of vitamin $\mathrm{D}$, $\mathrm{x}$ sev interaction $\mathrm{i}$.

e Linear effect of level of vitamin $D_{2}$ sig. $P<.05$ level.

e Linear effect of level of vitamin $\mathrm{D}_{2} 5 i g$. P $<.05$
$\mathrm{f}$ Treatment $\mathrm{x}$ sex interaction sig. $\mathrm{P}<.05$ level.

$g$ Difference between treatments $A$ and $B$ sig. $P<.05$ level.

$\mathrm{h}$ Non-linear effect of level of vitamin $\mathrm{D}_{2}$ sig. $\mathrm{P}<.05$ level.

1 Linear effect of level of cholesterol sig. $\mathrm{P}<.05$ level.

1 Non-linear effect of level of vitamin $D_{2} x$ sex interaction sig. $P<.01$ level.

$\mathrm{k}$ Non-linear effect of level of cholesterol $\mathrm{x}$ sex interaction sig. $\mathrm{P}<.05$ level.

1 Sex $x A$ and $B$ interaction sig. $\mathrm{P}<.05$ level.

gilts contained a larger percentage of myristic and stearic acid $(\mathrm{P}<.01)$ than that from barrows $(2.7$ vs. $2.5 \%$ and 11.2 vs. $10.6 \%$, respectively). Conversely, the intramuscular fat from barrows contained more oleic acid $(45.0$ vs. $44.2 \%)$ than fat from gilts. The data suggest intramuscular fat from gilts is more highly saturated than that from bar- rows. This observation does not agree with Koch et al. (1968) who reported that the fatty acid composition of intramuscular fat did not differ between barrows and gilts.

The addition of vitamin $\mathrm{D}_{2}$ to the basal diet caused a significant $(\mathrm{P}<.05)$ increase in intramuscular oleic acid of both barrows and gilts. A significant $(\mathrm{P}<.05)$ non-linear 
effect of level of dietary cholesterol $x$ sex interaction was also observed with oleic acid.

There was no significant treatment or sex difference for the palmitic, palmitoleic or linoleic acid contents of the intramuscular fat. A significant $(\mathrm{P}<.05)$ treatment and treatment $x$ sex interaction occurred with stearic acid content to the extent that in gilts, the acid pattern was increased by a linear increase in dietary vitamin $\mathrm{D}_{2}(\operatorname{diets} \mathrm{C}, \mathrm{D}, \mathrm{E})$ while a non-linear effect occurred in intramuscular fat of barrows. Since the total saturated fatty acid level paralleled stearic acid, the data suggest that increased levels of dietary vitamin $D_{2}$ caused the intramuscular fat to be more highly saturated.

A significant non-linear effect $(P<.05)$ on myristic acid level of the inner backfat layer occurred with linear increases in level of dietary vitamin $\mathbf{D}_{2}$. Myristic acid content was maximum at the intermediate level of dietary vitamin $\mathrm{D}_{2}(1,100 \mathrm{IU} / \mathrm{kg})$. This was not observed in the outer backfat laver.

The level of palmitic acid of the inner backfat layer was not affected by dietary treatment while that in the outer layer was significantly $(\mathrm{P}<.05)$ increased when vitamin $\mathrm{D}_{2}$ was added to the basal diet (diet $\mathrm{A} v s$. B).

The inner backfat layer of gilts contained more $(\mathrm{P}<.05)$ palmitoleic acid than that of barrows. A significant $(\mathrm{P}<.05)$ non-linear effect of level of cholesterol $x$ sex interaction occurred with palmitoleic acid of the outer backfat layer.

A linear increase in level of dietary cholesterol resulted in a significant $(\mathrm{P}<.05)$ increase in level of stearic acid of the inner backfat layer. The stearic acid content of the outer backfat layer was not significantly changed by dietary treatment. Since total saturated fatty acid content paralleled stearic acid in both layers of backfat, it is possible that increases in dietary cholesterol may result in increased saturation of the backfat tissue.

A significant treatment $x$ sex interaction occurred with the oleic acid content of both backfat layers. No explanation is apparent for this relationship.

A linear increase in the level of dietary vitamin $\mathrm{D}_{2}(\operatorname{diets} \mathrm{C}, \mathrm{D}, \mathrm{E})$ resulted in a significant $(\mathrm{P}<.05)$ increase of linoleic acid content of the inner backfat layer. No differences were observed in the linoleic acid content of the outer backfat layer. The backfat from gilts contained more linoleic acid than that of barrows which is consistent with the findings of Koch et al. (1968).

Overall, total saturated fatty acid content was higher in the inner backfat layer compared to the outer layer (42.8 vs. $38.6 \%$ ). This too is in agreement with the findings of Sink et al. (1964) and Koch et al. (1968).

Experiment 3. Table 4 shows a summary of the effects of dietary cholesterol and vitamin $D_{3}$ on blood and carcass traits of pigs from Experiment 3. Average backfat thickness was not significantly affected by dietary treatment and as expected from the previous experiments and other research, barrows had significantly $(\mathrm{P}<.05)$ more overall backfat thickness than gilts ( 5.1 vs. $4.6 \mathrm{~cm})$.

Area of the $l$. dorsi and percent of fat therein were larger $(\mathrm{P}<.01)$ and smaller, respectively, in gilts compared to barrows (33.9 vs. $30.5 \mathrm{~cm}^{2}$ and 2.9 vs. $3.8 \%$ ). Both observations were consistent with results reported in the previous experiment.

Carcasses of pigs fed diets containing supplemental cholesterol had less $l$. dorsi intramuscular fat than the nonsupplemented pigs (2.8 vs. 3.8\% No explanation is apparent for this occurrence.

Pigs fed diets containing supplemental cholesterol had higher levels of final blood serum cholesterol than the non-supplemented group (106.3 vs. $102.1 \mathrm{mg} / 100 \mathrm{ml}$ ). This increase was not statistically significant, but the trend agrees with observations in the previous experiments.

Since the initial blood cholesterol content was quite variable among the experimental treatments, the percent change between initial and final blood levels presents a clearer picture of the effect of dietary treatment. Final blood cholesterol of pigs fed the basal diet increased $3.8 \%$ over initial levels while that of the pigs fed supplemental vitamin $\mathrm{D}_{3}$ declined $4.1 \%$. Final blood cholesterol levels of pigs fed supplemental cholesterol increased 13.6 and $7.1 \%$ without and with vitamin $\mathrm{D}_{3}$, respectively. The data suggest a hypocholesterolemic effect of vitamin $D_{3}$ in the presence of absence of dietary cholesterol which is in agreement with results of the previous experiments using vitamin $\mathrm{D}_{2}$.

The cholesterol content of the liver was not significantly changed due to dietary treatment although livers of pigs fed supplemental cholesterol contained higher levels than the non-supplemented group (1.93 vs. $1.87 \mathrm{mg}$ / $\mathrm{g})$. Studies with rats have also indicated increased liver cholesterol levels resulting from 
TABLE 4. EFFECT OF LEVELS OF CHOLESTEROL AND VITAMIN $D_{3}$ ON BLOOD AND CERTAIN CARCASS TRAITS. (EXPERIMENT 3)

\begin{tabular}{|c|c|c|c|c|c|c|}
\hline \multirow[b]{3}{*}{ Item } & \multirow{2}{*}{\multicolumn{2}{|c|}{ Sex }} & \multicolumn{4}{|c|}{ Treatments (Cholesterol/Vitamin $D_{3}$ ) } \\
\hline & & & \multirow{2}{*}{$\begin{array}{l}\mathrm{A} \\
0 / 0\end{array}$} & \multirow{2}{*}{$\stackrel{\mathbf{B}}{0 / 1100}$} & \multirow{2}{*}{$\begin{array}{c}\mathrm{C} \\
440 / 0 \\
\end{array}$} & \multirow{2}{*}{$\begin{array}{c}D \\
440 / 1100 \\
\end{array}$} \\
\hline & Barrows & Gilts & & & & \\
\hline No. pigs ${ }^{a}$ & 12 & 12 & 6 & 6 & 6 & 6 \\
\hline Avg backfat, $\mathrm{cm}^{\mathrm{b}}$ & 5.1 & 4.6 & 4.8 & 4.8 & 4.6 & 5.2 \\
\hline L. dorsi area, $\mathrm{cm}^{2 \mathrm{~b}}$ & 30.5 & 33.9 & 32.2 & 31.6 & 32.1 & 32.8 \\
\hline L. dorsi fat, \% & 3.8 & 2.9 & 3.4 & 4.2 & 3.1 & 2.5 \\
\hline $\begin{array}{l}\text { Initial blood chol., } \\
\mathrm{mg} / 100 \mathrm{ml}\end{array}$ & 97.0 & 101.0 & 96.0 & 109.0 & 93.0 & 100.0 \\
\hline $\begin{array}{l}\text { Final blood chol., } \\
\mathrm{mg} / 100 \mathrm{ml}\end{array}$ & 107.0 & 101.0 & 99.0 & 104.0 & 105.0 & 107.0 \\
\hline $\begin{array}{l}\text { Liver chol., } \mathrm{mg} / \mathrm{g} \\
\text { wet tissue } \\
\text { L. dorsi chol., } \mathrm{mg} / \mathrm{g}\end{array}$ & 1.91 & 1.89 & 1.94 & 1.80 & 1.85 & 2.01 \\
\hline wet tissue & 0.45 & 0.45 & 0.44 & 0.44 & 0.45 & 0.46 \\
\hline $\begin{array}{l}\text { Inner backfat chol., } \\
\mathrm{mg} \text { /g wet tissue }\end{array}$ & 0.50 & 0.48 & 0.49 & 0.49 & 0.46 & 0.52 \\
\hline $\begin{array}{l}\text { Outer backfat chol., } \\
\text { mg/g wet tissue }\end{array}$ & 0.52 & 0.53 & 0.48 & 0.51 & 0.54 & 0.57 \\
\hline \multicolumn{7}{|c|}{$\begin{array}{l}\text { Fatty acid composition } \\
\text { Liver }\end{array}$} \\
\hline $\begin{array}{l}\text { 14:0 } \\
\text { 16:0 } \\
\text { 18:0 } \\
\text { Total for sat'd. } \\
\text { 16:1 } \\
18: 1 \\
18: 2\end{array}$ & $\begin{array}{r}1.2 \\
21.6 \\
29.0 \\
51.8 \\
+d \\
26.9 \\
21.3\end{array}$ & $\begin{array}{c}1.2 \\
24.2 \\
28.0 \\
54.2 \\
+ \\
25.2 \\
21.4\end{array}$ & $\begin{array}{l}1.1 \\
24.1 \\
25.7 \\
50.9 \\
+ \\
28.4 \\
20.7\end{array}$ & $\begin{array}{c}1.2 \\
22.4 \\
33.3 \\
56.9 \\
+ \\
22.3 \\
20.8\end{array}$ & $\begin{array}{c}1.3 \\
22.0 \\
29.7 \\
53.0 \\
+ \\
26.4 \\
20.6\end{array}$ & $\begin{array}{c}1.1 \\
23.2 \\
25.3 \\
49.6 \\
+ \\
27.1 \\
23.3\end{array}$ \\
\hline \multicolumn{7}{|c|}{ Intramuscular fat of $l$. dorsi } \\
\hline $\begin{array}{l}14: 0^{\mathrm{e}} \\
16: 0^{\mathrm{e}} \\
18: 0^{\mathrm{f}} \\
\text { Total for sat'd. } \\
\text { 16:1 } \\
\text { 18:1 } \\
18: 2^{\mathrm{i}, \mathrm{h}}\end{array}$ & $\begin{array}{r}2.2 \\
30.1 \\
9.6 \\
41.9 \\
6.1 \\
40.3 \\
11.6\end{array}$ & $\begin{array}{r}2.1 \\
31.2 \\
8.7 \\
42.0 \\
5.6 \\
40.6 \\
11.7\end{array}$ & $\begin{array}{r}2.0 \\
30.5 \\
9.0 \\
41.5 \\
6.3 \\
42.3 \\
9.9\end{array}$ & $\begin{array}{r}2.4 \\
29.9 \\
8.2 \\
40.5 \\
5.6 \\
41.7 \\
12.2\end{array}$ & $\begin{array}{r}2.1 \\
31.1 \\
9.0 \\
42.2 \\
5.7 \\
40.5 \\
11.6\end{array}$ & $\begin{array}{r}2.1 \\
31.2 \\
10.2 \\
43.6 \\
6.0 \\
37.3 \\
13.1\end{array}$ \\
\hline \multicolumn{7}{|l|}{ Inner backfat } \\
\hline $\begin{array}{l}\text { 14:0 } \\
16: 0 \\
\text { 18:0 } \\
\text { Total for sat'd. } \\
\text { 16:1 } \\
18: 1 \\
18: 2\end{array}$ & $\begin{array}{r}1.8 \\
26.9 \\
11.8 \\
40.6 \\
4.0 \\
45.8 \\
9.6\end{array}$ & $\begin{array}{r}2.2 \\
27.2 \\
10.6 \\
40.0 \\
4.2 \\
45.7 \\
10.0\end{array}$ & $\begin{array}{r}2.1 \\
26.7 \\
11.2 \\
40.0 \\
4.1 \\
45.3 \\
10.6\end{array}$ & $\begin{array}{r}1.8 \\
27.1 \\
10.6 \\
39.6 \\
4.2 \\
46.6 \\
9.6\end{array}$ & $\begin{array}{r}2.1 \\
26.8 \\
11.2 \\
40.1 \\
4.3 \\
44.7 \\
10.8\end{array}$ & $\begin{array}{r}2.1 \\
27.5 \\
11.8 \\
41.4 \\
3.8 \\
46.5 \\
8.2\end{array}$ \\
\hline \multicolumn{7}{|l|}{ Outer backfat } \\
\hline $\begin{array}{l}\text { 14:0 } \\
16: 0 \\
\text { 18:0 } \\
\text { Total for sat'd. } \\
16: 1^{\text {h }} \\
18: 1^{1} \\
18: 2\end{array}$ & $\begin{array}{r}2.0 \\
25.2 \\
9.2 \\
36.4 \\
4.9 \\
47.3 \\
11.5\end{array}$ & $\begin{array}{r}2.2 \\
25.9 \\
8.5 \\
36.6 \\
4.7 \\
46.6 \\
12.1\end{array}$ & $\begin{array}{r}2.4 \\
25.1 \\
9.3 \\
36.8 \\
5.3 \\
45.1 \\
13.1\end{array}$ & $\begin{array}{r}2.0 \\
25.0 \\
8.0 \\
35.0 \\
4.7 \\
48.6 \\
11.7\end{array}$ & $\begin{array}{r}2.3 \\
25.7 \\
9.3 \\
37.3 \\
4.8 \\
45.8 \\
12.1\end{array}$ & $\begin{array}{r}1.8 \\
26.3 \\
8.9 \\
37.0 \\
4.4 \\
48.3 \\
10.3\end{array}$ \\
\hline
\end{tabular}

a One pen of six pigs per treatment.

c Level of cholesterol $\mathrm{x}$ vitamin $\mathrm{D}_{3}$ interaction sig. $\mathrm{P}<.05$ level.

d $+=$ traces, but amount was too small to measure.

e Sex $x$ level of cholesterol interaction sig. P<.05 level.

$f$ Sex $x$ level of cholesterol $x$ level of vitamin $\mathrm{D}_{3}$ interaction sig. $\mathrm{P}<.01$ level.

$g$ Difference due to level of cholesterol sig. $\mathrm{P}<.05$ level.

h Sex $x$ level of vitamin $D_{3}$ interaction sig. $P<.05$ level.

$t$ Difference due to level of vitamin $D_{3}$ sig. $P<.05$ level. 
dietary cholesterol (Cuthbertson et al., 1959; Pack and Loud, 1965). The highest content of cholesterol occurred in livers of pigs fed vitamin $D_{3}$ in combination with cholesterol. This would suggest that vitamin $D_{3}$ may in effect play a homeostatic role in blood cholesterol level by increased retention of cholesterol in the liver. A similar concept has been reported concerning the hypocholesterolemic action of the polyunsaturated fatty acids (Alpert and Geller, 1968).

The cholesterol content of $l$. dorsi and inner and outer layers of backfat followed a pattern similar to that of final blood levels. Supplementing the diet with either cholesterol or vitamin $\mathrm{D}_{3}$ caused slight increases in the tissue cholesterol content.

The fatty acid content of the liver, $l$. dorsi intramuscular fat, and inner and outer layers of backfat of pigs in Experiment 3 is also summarized in table 4 . The fatty acid composition in the liver differed from that of the muscle or backfat in that the principal saturated fatty acid in the liver was stearic rather than palmitic acid. Oleic acid was the primary unsaturate in all the tissues studied.

There was no significant treatment or sex effect on any of the liver fatty acids studied except stearic acid which increased as vitamin $D_{3}$ was added to the basal diet and decreased when vitamin $D_{3}$ was fed in combination with cholesterol.

The total saturated fatty acid content was much higher in the liver compared to other tissues and its pattern paralleled stearic acid.

No explanation can be given as to why the palmitoleic acid of the liver was not present in large enough amounts to be measured accurately. The level of linoleic acid remained fairly constant while the oleic acid content varied with the deposition of total saturated fatty acids.

The myristic, palmitic and total saturated fatty acid contents of the $l$. dorsi intramuscular fat increased and decreased in barrows and gilts, respectively, when cholesterol was included in the diet. The sex $x$ level of cholesterol interaction was significant $(\mathrm{P}<.05)$. The level of stearic acid was increased in both barrows and gilts with the inclusion of dietary cholesterol. Although not significant, the $l$. dorsi intramuscular fat of gilts appeared to be more highly saturated than that of barrows which is consistent with findings in the previous experiment.

There was no significant treatment differ- ence for palmitoleic acid in the $l$. dorsi intramuscular fat. A reduction $(\mathrm{P}<.05)$ in oleic acid content was observed in pigs fed supplemental cholesterol compared to the nonsupplemented group (38.9 vs. 42.0\%). The addition of vitamin $\mathrm{D}_{3}$ to the diet increased and decreased oleic acid content of $l$. dorsi intramuscular fat in gilts and barrows, respectively. Linoleic acid content was elevated $(\mathrm{P}<.05)$ in $l$. dorsi intramuscular fat of pigs fed supplemental vitamin $\mathrm{D}_{3} \quad(12.6$ vs. $10.7 \%$ ).

There was no significant treatment or sex difference for the fatty acid pattern in the inner backfat layer. The addition of vitamin $D_{3}$ to the diet caused a reduction and elevation in palmitoleic acid content of the outer backfat layer of barrows and gilts, respectively. The oleic acid content of the outer backfat layer increased significantly $(\mathrm{P}<.05)$ with the addition of vitamin $\mathrm{D}_{3}$ to the diet. The data indicate an inverse relationship in the pattern of oleic acid between the backfat and $l$. dorsi intramuscular fat.

The total saturated fatty acid pattern of the backfat paralleled that of the muscle tissue. The inner layer of backfat was more highly saturated than the outer layer which is in agreement with results of the previous experiment. Backfat of barrows (both layers) contained more total saturated fatty acids than that from gilts.

It appears from the data that the addition of cholesterol to the diet caused an increase in total saturated fatty acids of the backfat and muscle tissue while those in the liver were reduced. When vitamin $D_{3}$ was supplemented to the basal diet, total saturated fatty acids of the backfat and muscle tissue were reduced while those in the liver were increased. The opposite was observed when vitamin $\mathrm{D}_{3}$ was fed in combination with cholesterol.

There has been some disagreement as to which layer of backfat undergoes the greatest fatty acid change in response to diet. Bhattacharya and Hilditch (1961) reported that the most intensive changes occurred in the inner layer, while Garton, Hilditch and Meara (1952) indicated greater changes occurred in the outer layer. Sink et al. (1964) and Koch et al. (1968) found selective deposition of total saturated fatty acids increased with maturity and preferential deposition in the inner rather than the outer backfat layer. In the present study, total saturated fatty acid content was higher in the inner backfat layer 
compared to the outer layer thus indicating the inner layer of backfat undergoes a greater fatty acid change and was deposited subsequent to the outer layer.

\section{Summary}

Three experiments involving 144 crossbred barrows and gilts were conducted to determine the effects of dietary supplements of vitamin $\mathrm{D}$ and cholesterol upon blood cholesterol and the cholesterol and fatty acid content of certain tissues of growing-finishing swine.

Supplementing the diet with crystalline cholesterol resulted in nonsignificant elevations final blood serum and liver cholesterol levels. The blood and liver cholesterol levels of barrows tended to be greater than those of gilts.

Final blood cholesterol levels consistently declined or at least were stabilized by the addition of vitamin $D_{2}$ or $D_{3}$ to the swine diets. When high levels of vitamin $\mathrm{D}_{3}$ and cholesterol were fed in combination, the blood level of cholesterol was reduced while that of the liver was increased. These findings indicate that the hypocholesterolemic effect of vitamin $\mathrm{D}$ may be in part related to increased liver cholesterol retention or deposition.

The cholesterol content of the $l$. dorsi intramuscular fat and the inner and outer layers of backfat was quite similar with small variations due to dietary treatment. The fatty acid pattern of the three tissues was also similar but concentration varied with dietary treatment. The $l$. dorsi intramuscular fat of gilts was more highly saturated than that of barrows. However, the backfat of barrows contained higher levels of total saturated fatty acids than that of gilts. The inner backfat layer was more highly saturated than the outer layer in both barrows and gilts. Data suggest that the inner layer of backfat exhibited a more extensive turnover of fatty acids and was deposited subsequent to the outer layer.

The results suggest that dietary intake of cholesterol causes increased deposition of saturated fatty acids and elevated blood cholesterol levels while dietary intake of vitamin D causes increased deposition of unsaturated fatty acids, primarily linoleic acid, and reduced blood cholesterol levels. Although the fatty acid pattern of pork tissue was changed by manipulation of diet, the cholesterol content remained quite stable.

\section{Literature Cited}

Alpert, L. I. and S. A. Geller, 1968. Effect of safflower oil on hepatic deposition of cholesterol. Fed. Proc. 27:665.

A.O.A.C. 1960. Official Methods of Analysis (9th Ed.). Association of Official Agricultural Chemists. Washington, D. C.

Bhattacharya, R. and T. P. Hilditch. 1931. The body fats of the pig. I. Influence of ingested fat on the component fatty acids. Biochem. J. 25:1954.

Brooks, C. C. 1967 . Effect of sex, soybean oil, bagasse and molasses on carcass composition and composition of muscle and fat tissue in swine. J. Anim. Sci. 26:504.

Bruner, W. H., V. R. Cahill, W. L. Robison and R. F. Wilson. 1958. Performance of barrow and gilt littermate pairs at the Ohio Swine Evaluation Station. J. Anim. Sci. 17:875.

Cox, D. F. 1963. Breed and sex effects on the relationship between weight and fatness measured at a constant age in swine. J. Anim. Sci. 22:1091.

Cuthbertson, W. F. J., P. V. Elcoate, D. M. Ireland, D. C. B. Mills and P. Shearley. 1959. Serumcholesterol levels and atherosclerosis: effects of composition of diet and tri-iodothyronine on the rat. Brit. J. Nutr. 13:227.

DeLangen, C. D. and W. F. Donth. 1956. Vitamin $D$ sclerosis of the arteries and danger of feeding extra vitamin $\mathrm{D}$ to older people. With a view on the development of different forms of atherosclerosis. Acta. Medica Scand. 156:317.

Garton, G. A., T. P. Hilditch and M. L. Meara. 1952. The composition of the depot fats of a pig fed on a diet rich in whale oil. Biochem. J. 50:517. Greer, S. A. N., V. W. Hays, V. C. Speer, J. T. McCall and E. G. Hammond. 1965. Effects of level of corn- and barley-base diets on performance and body composition of swine. J. Anim. Sci. 24:1008.

Hanahan, D. J. 1960. Lipid Chemistry. John Wiley and Sons, Inc., New York.

Hill, E. G., J. J. Peifer and W. O. Lundburg. 1958. Influence of sex and dietary phosphatides on cholesterol levels in blood plasma of swine. Proc. Soc. Exp. Biol. and Med. 99:586.

Judge, M. D. 1964. Comparisons of longissimus dorsi area of genetically similar barrows and gilts. J. Anim. Sci. 23:118.

Jurgens, M. H., D. B. Hudman, C. H. Adams and E. R. Peo, Jr. 1967. Influence of a dietary supplement of lysine fed at two levels of protein on growth, feed efficiency and carcass characteristics of swine. J. Anim. Sci. 26:323.

Koch, D. E., A. M. Pearson, W. T. Magee, J. A. Hoefer and B. S. Schweigert. 1968. Effect of diet on the fatty acid composition of pork fat. J. Anim. Sci. 27:360.

Morrison, W. R. and L. M. Smith. 1964. Preparation of fatty acid methyl esters and dimethylacetals from lipids with boron flouride-methanol. J. Lipid Res. 5:600.

Myasnikov, A. L. 1958. Influence of some factors on development of experimental cholesterol atherosclerosis. Circulation 17:99.

Pack, B. A. and A. V. Loud. 1965. The effect of altered rates of cholesterol biosynthesis on the concentration and distribution of squalene in rat livers. J. Cell Biol, 27:76. (Abstr.). 
Pearson, S., S. Stern and T. H. McGavack. 1953. A rapid, accurate method for determination of total cholesterol in serum. Anal. Chem. 25:813.

Reiser, M. F. 1959. Influence of high levels of dietary fats and cholesterol on atherosclerosis and lipid distribution in swine. Circulation Research $7: 833$.

Ross, F. C. H. and A. H. Campbell. 1961. The effect of vitamin $A$ and $D$ capsules upon incidence of coronary heart disease and blood cholesterol. Med. J. of Australia 48:307.

Self, H. L., R. W. Bray and R. J. Reierson. 1957. Lean cut yield and an evaluation of hams and loins of U.S.D.A. pork carcass grades. J. Anim. Sci. 16:642.
Sink, J. D., J. L. Watkins, J. H. Ziegler and R. C. Miller. 1964. Analysis of fat deposition in swine by gas-liquid chromotography. J. Anim. Sci. $23: 121$.

Steel, R. G. D. and J. H. Torrie. 1960. Principles and Procedures of Statistics. McGraw-Hill Book Co., New York.

Stromer, M. H., D. E. Goll and J. H. Roberts. 1966. Cholesterol in subcutaneous and intramuscular lipid depots from bovine carcasses of different maturity and fatness. J. Anim. Sci. 25:1145.

Wagner, G. R., A. J. Clark, V. W. Hays and V. C. Speer. 1963. Effect of protein-energy relationships on the performance and carcass quality of growing swine. J. Anim. Sci. 22:202. 